\title{
Localization of Postsynaptic Density-93 to Dendritic Microtubules and Interaction with Microtubule-Associated Protein 1A
}

\author{
Jay E. Brenman, ${ }^{1}$ J. Rick Topinka, ${ }^{1}$ Edward C. Cooper, ${ }^{1}$ Aaron W. McGee, ${ }^{1}$ Joel Rosen, ${ }^{1}$ Toni Milroy, ${ }^{1}$ \\ Henry J. Ralston, ${ }^{2}$ and David S. Bredt ${ }^{1}$ \\ Departments of ${ }^{1}$ Physiology and ${ }^{2}$ Anatomy, University of California at San Francisco, San Francisco, \\ California 94143-0444
}

Postsynaptic density-93 (PSD-93)/Chapsyn-110 is a member of the membrane-associated guanylate kinase (MAGUK) family of PDZ domain-containing proteins. MAGUKs are widely expressed in the brain and are critical elements of the cytoskeleton and of certain synapses. In the ultrastructural studies that are described here, PSD-93 localizes to both postsynaptic densities and dendritic microtubules of cerebellar Purkinje neurons. The microtubule localization is paralleled by a high-affinity in vivo interaction of PSD-93 via its guanylate kinase (GK) domain with microtubule-associated protein 1A (MAP1A). GK domain truncations that mimic genetically identified mutations of a Drosophila MAGUK, discs-large, disrupt the GK/MAP-1A interaction. Additional biochemical experiments demonstrate that intact MAGUKs do not bind to MAP1A as effectively as do isolated GK domains. This appears to be attributable to an intramolecular inhibition of the GK domain by the PDZs, because GK binding activity of full-length MAGUKs is partially restored by a variety of PDZ ligands, including the $C$ termini of NMDA receptor $2 \mathrm{~B}$, adenomatous polyposis coli (APC), and CRIPT. Beyond demonstrating a novel cytoskeletal link for PSD-93, these experiments support a model in which intramolecular interactions between the multiple domains of MAGUKs regulate intermolecular associations and thereby may play a role in the proper targeting and function of MAGUK proteins.

Key words: postsynaptic density; cytoskeleton; microtubules; dendrite; MAP1A; NMDA
A convergence of biochemical and genetic studies has identified the membrane-associated guanylate kinases (MAGUKs) as critical cytoskeletal elements responsible for synaptic function (Sheng, 1996; Kennedy, 1997; Kornau et al., 1997; Craven and Bredt, 1998). Postsynaptic density-95/synapse-associated protein-90 (PSD-95/SAP-90), the prototypical neuronal MAGUK, originally was identified as a major component of the postsynaptic density (Cho et al., 1992; Kistner et al., 1993). Molecular cloning shows PSD-95 to be homologous to both Drosophila discs-large (dlg) (Woods and Bryant, 1991), which regulates the structure and function of the larval neuromuscular junction (Lahey et al., 1994; Budnik et al., 1996; Guan et al., 1996; Tejedor et al., 1997; Thomas et al., 1997; Zito et al., 1997), and to lin-2, which is required for the induction of vulva development in Caenorhabditis elegans (Kim, 1995). MAGUKs appear to regulate synaptic function by mediating specific protein interactions. Indeed, MAGUKs contain classical protein-protein interaction motifs, including three N-terminal PDZ domains and an SH3 domain. MAGUKs also have a C-terminal region homologous to

Received May 28, 1998; revised July 13, 1998; accepted Aug. 14, 1998.

J.E.B. was supported by the American Heart Association. E.C.C. was supported by the National Institute of Neurological Diseases and Stroke, a Pfizer postdoctoral fellowship, and an AAN/Parke-Davis Young Investigator Award. This work also was supported by Grant NS36017 (to D.S.B.) from National Institutes of Health, the National Science Foundation, the National Association for Research on Schizophrenia and Depression, the EJLB Foundation, the Culpeper Foundation, the Beckman Foundation, and the Lucille P. Markey Charitable Trust and by Grant NS23347 (to H.J.R.) from National Institutes of Health. We thank Dr. Wendell Lim for helpful suggestions and Orien Wiener for assistance with microscopy.

J.E.B. and J.R.T. contributed equally to this work.

Correspondence should be addressed to Dr. David S. Bredt, University of California at San Francisco School of Medicine, 513 Parnassus Avenue, San Francisco, CA 94143-0444.

Copyright (C) 1998 Society for Neuroscience $\quad 0270-6474 / 98 / 188805-09 \$ 05.00 / 0$ guanylate kinase (GK), which, however, lacks apparent enzymatic activity.

Most biochemical studies of MAGUKs have focused on the PDZ domains, which bind the C-terminal tails of ion channels, including NMDA receptor subunits (Kornau et al., 1995) and Shaker type $\mathrm{K}^{+}$channels (Kim et al., 1995), a signaling enzyme SynGAP (Chen et al., 1998; Kim et al., 1998), and the microtubule-associated proteins adenomas polyposis coli (APC) (Matsumine et al., 1996) and CRIPT (Niethammer et al., 1998). The second PDZ motif of neuronal MAGUKs also binds neuronal nitric oxide synthase (nNOS) (Brenman et al., 1996a). These PDZ domain interactions may mediate ion channel clustering (Kim et al., 1995; Kornau et al., 1995) and may link synaptic receptors to downstream effectors (Brenman et al., 1996a). Ligands for the SH3 domain of MAGUKs are unknown, but two-hybrid studies have identified a family of GK domainassociated proteins (GKAPs or SAPAPs) (Kim et al., 1997; Takeuchi et al., 1997). Interestingly, most alleles of lin-2 and $\mathrm{dlg}$ occur in the GK domains, suggesting an essential role for this region of the proteins.

Here, we evaluated mechanisms for the association of MAGUKs with the neuronal cytoskeleton. We find that PSD-93/ Chapsyn-110 occurs both at the postsynaptic density and along dendritic microtubules in cerebellar Purkinje cells. Via expression cloning we identify a high-affinity $\left(\mathrm{EC}_{50}=7.5 \mathrm{nM}\right)$ interaction of the GK domain of neuronal MAGUKs with microtubuleassociated protein 1A (MAP1A), a major constituent of neuronal microtubules (Matus, 1988). PSD-93 and MAP1A colocalize in cerebellar Purkinje cells, and these two proteins specifically coimmunoprecipitate. The GK domain also binds to a set of 100$140 \mathrm{kDa}$ proteins enriched in the PSD. However, we find that full-length MAGUKs do not bind as effectively as isolated GK 
domains to MAP1A or to the $100-140 \mathrm{kDa}$ proteins because of autoinhibition by the PDZ domains. GK binding activity of the full-length protein is stimulated (up to ninefold) by apparent PDZ domain displacement mediated by ligands to the PDZ domains. This work suggests that PDZ domain occupation may modulate GK function in MAGUK proteins.

\section{MATERIALS AND METHODS}

Overlay analysis and expression cloning. A protein kinase A (PKA) consensus phosphorylation site was inserted at the $3^{\prime}$ end of full-length PSD-95 and SAP-97 GST fusion constructs in pGEX-2T (generous gifts from Dr. Craig Garner, University of Alabama, Birmingham, AL). The fusion proteins were expressed in Escherichia coli, purified with glutathione Sepharose, and labeled with $\gamma\left[{ }^{32} \mathrm{P}\right] \mathrm{ATP}$ as described (Blanar and Rutter, 1992). For overlay analysis, detergent-solubilized rat brain or liver extracts $(100 \mu \mathrm{g} /$ lane $)$ were resolved by $6 \%$ SDS-PAGE and transferred to nitrocellulose membranes. Filters were blocked for $1 \mathrm{hr}$ in overlay buffer [30 mM Tris-HCl-buffered saline containing $0.1 \%$ Tween-20 (TBST) supplemented with $1 \%$ nonfat dry milk and 1\% BSA] and then were incubated for $4 \mathrm{hr}$ in the same solution containing ${ }^{32} \mathrm{P}$-labeled PSD-95 $\left(10^{5} \mathrm{cpm} / \mathrm{ml}\right)$. Filters were washed two times for 10 min in TBST and exposed to $x$-ray film. A $\lambda$ GT11 rat brain cDNA library (Clontech, Palo Alto, CA) was screened with ${ }^{32} \mathrm{P}$-labeled PSD-95 exactly as described (Vinson et al., 1988). GST fusion proteins encoding the PDZ [amino acids (aa) 1-415], SH3 (aa 408-501), and GK (aa 503-721) of PSD-95 were engineered with $3^{\prime}$ PKA sites. These expressed and purified fusion proteins were labeled with $\left[{ }^{32} \mathrm{P}\right]$ and used to screen interacting plaques at the second round of purification. For quantitative binding assays, $100 \mathrm{ng}$ of purified histidine-tagged MAP1A fusion protein (aa 1860-2085) was immobilized on a nitrocellulose membrane and incubated in overlay buffer with ${ }^{32} \mathrm{P}$-labeled GK domain or full-length MAGUK GST fusion proteins. Membranes were washed as described above, and bound radioactivity was quantitated by scintillation counting. The $\mathrm{EC}_{50}$ for the interaction of GK with MAP1A was determined by quantitative saturation binding assays, as described above. Unlabeled GK-GST was used to compete with radiolabeled GK-GST for binding to purified recombinant histidine-tagged MAP1A immobilized on nitrocellulose. All quantitative binding assays were done in triplicate.

Immunocytochemistry. For immunofluorescence the rats were perfused with $4 \%$ paraformaldehyde and cryoprotected with $20 \%$ sucrose. Free-floating brain sections $(40 \mu \mathrm{m})$ were labeled with monoclonal antibodies to MAP1A (Sigma, St. Louis, MO), MAP2 (Sigma), and a polyclonal guinea pig antiserum to PSD-93 (Brenman et al., 1996b). Indirect immunofluorescence was detected with donkey anti-mouse $\mathrm{Cy}-2$ (1:200) and donkey anti-guinea pig Cy-3 (1:200) (Jackson ImmunoResearch, West Grove, PA). For immunoelectron microscopy the rats were perfused with fixative containing $2 \%$ paraformaldehyde and $1 \%$ glutaraldehyde; vibratome-cut cerebellar sections were permeabilized by incubation in $50 \%$ ethanol for 30 min before being blocked with $3 \%$ normal goat serum. Immunoreactions were performed on floating sections in the presence of $0.1 \% \mathrm{NiCl}$, using a Vectastain Elite kit according to the manufacturer's instructions (Vector Laboratories, Burlingame, CA). Immunoreacted sections were washed in phosphate buffer, osmicated (1\% osmium tetraoxide, $\mathrm{pH} 5.5$, for $1 \mathrm{hr})$, stained with $1 \%$ uranyl acetate (for $1 \mathrm{hr}$ ), dehydrated through ethanol and propylene oxide, and flat-embedded in Epon on plastic slides under Aclar coverslips. Silvergold $(\sim 80 \mathrm{~nm})$ ultrathin sections were cut, collected on Butvar-coated slot grids with Reynolds lead citrate and uranyl acetate, and photographed at 5600-19,000 $\times$ magnification.

Overlay filter binding assays. "Far Western" assay was performed as described (Kim et al., 1997). PSD-95 constructs [FL (full-length), $\triangle$ PDZ1 (aa 158-721), $\triangle$ PDZ1-2 (aa 311-721), and $\triangle$ PDZ1-3 (aa 408721)] were subcloned into pRSET A (hexa-histidine expression vector; Invitrogen, San Diego, CA), and the appropriate histidine-tagged proteins were expressed and purified from E. coli. A fragment of MAP1A encoding amino acids 1616-1962 was subcloned into pGEX-4T, and the GST fusion protein was expressed and purified. GST-MAP1A and GST control proteins were resolved on SDS-PAGE and transferred to nitrocellulose. Filters were overlaid with histidine-tagged PSD-95 constructs $(0.5 \mu \mathrm{g} / \mathrm{ml})$. A peptide mimicking the tail of the NMDA receptor 2B, NR2B (full sequence KLSSIESDV), a mutated peptide NR2B* (KLSSIESDA), NR2B** (KLSSIEADA), APC (SGSYLVTSV), K $\mathrm{v}_{\mathrm{v}} 1.4$ (NAKAVETDV), and CRIPT (TKNYKQTSV) was added to the overlay buffer when indicated. Bound PSD-95 fusion proteins were detected by ECL, using an Omni-probe (M-21) antibody directed against the histidine-tagged fusion protein (Santa Cruz Biotechnologies, Santa Cruz, CA).

Immunoprecipitation, tissue fractionation, and fusion protein affinity chromatography. Synaptic membranes and PSDs were prepared as described (Cohen et al., 1996). Microtubules were purified from brain tissue by using the taxol method exactly as described (Vallee, 1986). Immunoprecipitation and GST affinity chromatography assays from brain extracts were performed as described (Brenman et al., 1996a), except that crude rat brain homogenates were extracted with $1 \%$ Triton X-100 for $1 \mathrm{hr}$ at $4^{\circ} \mathrm{C}$. GST fusions are as follows: GK-93 (aa 610-825), GK-95 (aa 503721), GK-97 (aa 654-908), PSD-95-SH3 (aa 408-501), PSD-95PDZ(1-3) (aa 1-415), and PSD-95-GK mutant (aa 503-698).

\section{RESULTS}

\section{PSD-93 in Purkinje neurons occurs along dendritic microtubules and at the PSD}

Cerebellar Purkinje neurons are uniquely endowed with a single known MAGUK, PSD-93 (Chapsyn-110) (Brenman et al., 1996b; Kim et al., 1996), and thus offer an ideal system for the analysis of MAGUK function. As previously described, PSD-93 staining is dense within Purkinje cell bodies and in their large proximal dendritic shafts (Brenman et al., 1996b; Kim et al., 1996). At the light microscopic level, diff use staining is also apparent throughout the molecular layer. No PSD-93 immunolabeling is seen in the granule cell layer (Fig. $1 A$ ). Labeling is absent in sections incubated with the preimmune antisera (Fig. $1 B$ ).

To localize PSD-93 at the subcellular level, we examined immunoperoxidase-stained cerebellar sections by immunoelectron microscopy. Reaction product within the Purkinje cell and molecular layers was restricted to the cell bodies and dendritic arbors of the Purkinje cells. Within the large proximal portions of Purkinje cell dendrites (Fig. $1 C$ ), microtubules were heavily labeled. Adjacent organelles, including mitochondria and the Purkinje cell plasma membrane, were not stained. Microtubules in adjacent granule cell parallel fiber axons were unstained. Within the outer molecular layer, where Purkinje cells receive excitatory input from parallel fiber boutons, many synaptic spines exhibited staining that was associated with their PSDs and surface membranes (Fig. 1D). No staining of microtubules or PSDs was observed in control sections processed without immune serum (data not shown).

\section{The GK domain of MAGUKs binds MAP1A and to proteins in the PSD}

To identify proteins that anchor MAGUKs to the neuronal cytoskeleton, we probed for interacting protein bands, using gel overlay analysis. Crude brain homogenates were resolved on SDS-PAGE gels and transferred to nitrocellulose; filters were hybridized with radiolabeled PSD-95 protein. A protein band of $\sim 350 \mathrm{kDa}$ and a set of bands of $\sim 100-140 \mathrm{kDa}$ were identified in brain extracts. No strong interacting bands were found in liver extracts (Fig. 2A). Expression cloning from a $\lambda \mathrm{GT} 11$ rat brain cDNA library was used to identify interacting proteins. From a screen of $0.5 \times 10^{6}$ phage, nine specific interacting clones were obtained. Six clones corresponded to C-terminal fragments of rat APC protein, a protein that previously has been shown to associate with HDLG (SAP-97), a MAGUK present in neurons (Matsumine et al., 1996). The remaining three clones encoded overlapping regions of MAP1A, a brain-specific microtubuleassociated protein (Langkopf et al., 1992). The PDZ domains of neuronal MAGUKs bind to the C terminus of APC (Matsumine et al., 1996). To determine which MAGUK protein domain binds MAP1A, we hybridized the interacting clones with radiolabeled 

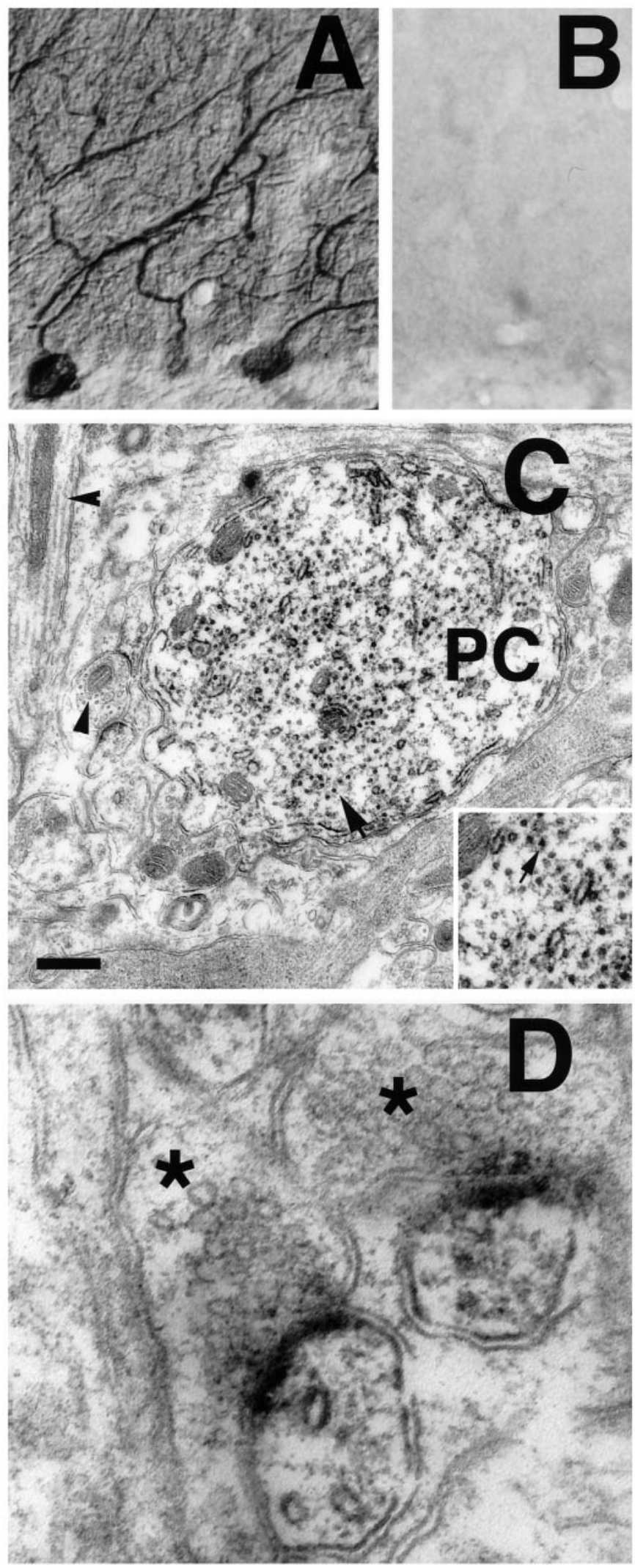

Figure 1. Ultrastructural localization of PSD-93 in cerebellar Purkinje neurons. Immunoperoxidase staining of rat cerebellum demonstrates that PSD-93 is enriched in Purkinje cell bodies and dendritic arbors in the molecular layer $(A)$; no labeling is seen in sections incubated with preimmune serum $(B)$. Electron micrography of a thin section from the fusion proteins corresponding to the PDZ, SH3, or GK domain. Only the GK domain bound MAP1A (Fig. 2B).

We then characterized the MAP1A/GK domain interface by yeast two-hybrid analysis. The three interacting MAP1A clones overlapped in only a small region corresponding to amino acids 1860-1962 (Fig. 2C), a segment that is strongly conserved between human and rat MAP1A cDNAs but that has no sequence homology with other known genes. We found that the GK domain interacts specifically with a construct that encodes only these 103 amino acids of overlap (Table 1). This GK binding domain is juxtaposed to the identified microtubule-nucleating zone of MAP1A (Fig. 2C) (Cravchik et al., 1994). Certain alleles of $d l g$ from Drosophila or lin-2 from C. elegans involve truncations of the GK domain of these MAGUK proteins. One mutation of lin-2 removes only the final 22 amino acids (Hoskins et al., 1996). A similar truncation of the GK domain eliminates binding to MAP1A. A nearly complete GK domain appears to be necessary for interaction, because deletion of the first 57 amino acids also eliminates binding to MAP1A (Table 1).

MAP1A is a $350 \mathrm{kDa}$ protein (Matus, 1988) and seemed likely to represent the high molecular weight band that was detected by gel overlay analysis. In fact, we found that all of the protein bands in brain extracts detected by overlay analysis selectively bound the GK domain (Fig. 3A). No prominent bands were detected in overlays of crude brain homogenates with the PDZ or $\mathrm{SH} 3$ domains (data not shown). Immunoprecipitation experiments confirmed that the $350 \mathrm{kDa}$ GK-interacting band observed by overlay analysis is MAP1A (Fig. 3A). Overlay analysis of subcellular fractions showed that the $350 \mathrm{kDa}$ band partitions with microtubules, whereas the 100-140 kDa bands are enriched in the postsynaptic density (Fig. $3 A$ ). Immunoprecipitation of detergent-solubilized PSD fraction demonstrates that the 100 $140 \mathrm{kDa}$ proteins associate with PSD-95 in vivo (Fig. $3 A$ ). Saturation binding shows that the MAP1A/GK domain interaction is of high affinity, $\mathrm{EC}_{50}=7.5 \mathrm{~nm}$ (Fig. $3 B$ ).

\section{PSD-93 and MAP1A associate in vivo}

To determine whether the GK domains of MAGUKs bind to MAP1A protein in brain extracts, we performed affinity chromatography experiments. MAP1A from brain extracts bound to GK domains from PSD-95, PSD-93, and SAP-97 (HDLG), but it did not interact with the PDZ or SH3 domains of PSD-95 (Fig. 4A). By contrast, neuronal nitric oxide synthase (nNOS) was retained selectively by a PDZ domain column (Brenman et al., 1996a). A 22-amino-acid C-terminal truncation of the GK domain that corresponds to a lin-2 mutation (Hoskins et al., 1996) abolished interaction with MAP1A (Fig. 4A).

Previous studies have shown that MAP1A binds to microtubules, actin, and neurofilaments (Pedrotti et al., 1994) and occurs in a somatodendritic pattern in various neuronal populations,

$\leftarrow$

molecular layer $(C)$ shows specific labeling of microtubules (arrows), smooth endoplasmic reticulum, and membranous subsurface cisterns in a Purkinje cell $(P C)$ dendrite cut in cross section. The unstained profiles at the left of the Purkinje cell provide examples of unstained microtubules seen both lengthwise and in cross section (arrowheads). Inset shows at higher magnification a portion of the Purkinje cell dendrite containing stained endoplasmic reticulum and microtubules (arrow) as well as some unstained microtubules. $D$, Stained Purkinje cell spines in the outer molecular layer. Immunoreaction product labels surface membranes of spine and postsynaptic densities. Scale bars: $0.5 \mu \mathrm{m}$ in $C ; 0.3 \mu \mathrm{m}$ in $C$, inset; $0.1 \mu \mathrm{m}$ in $D$. 

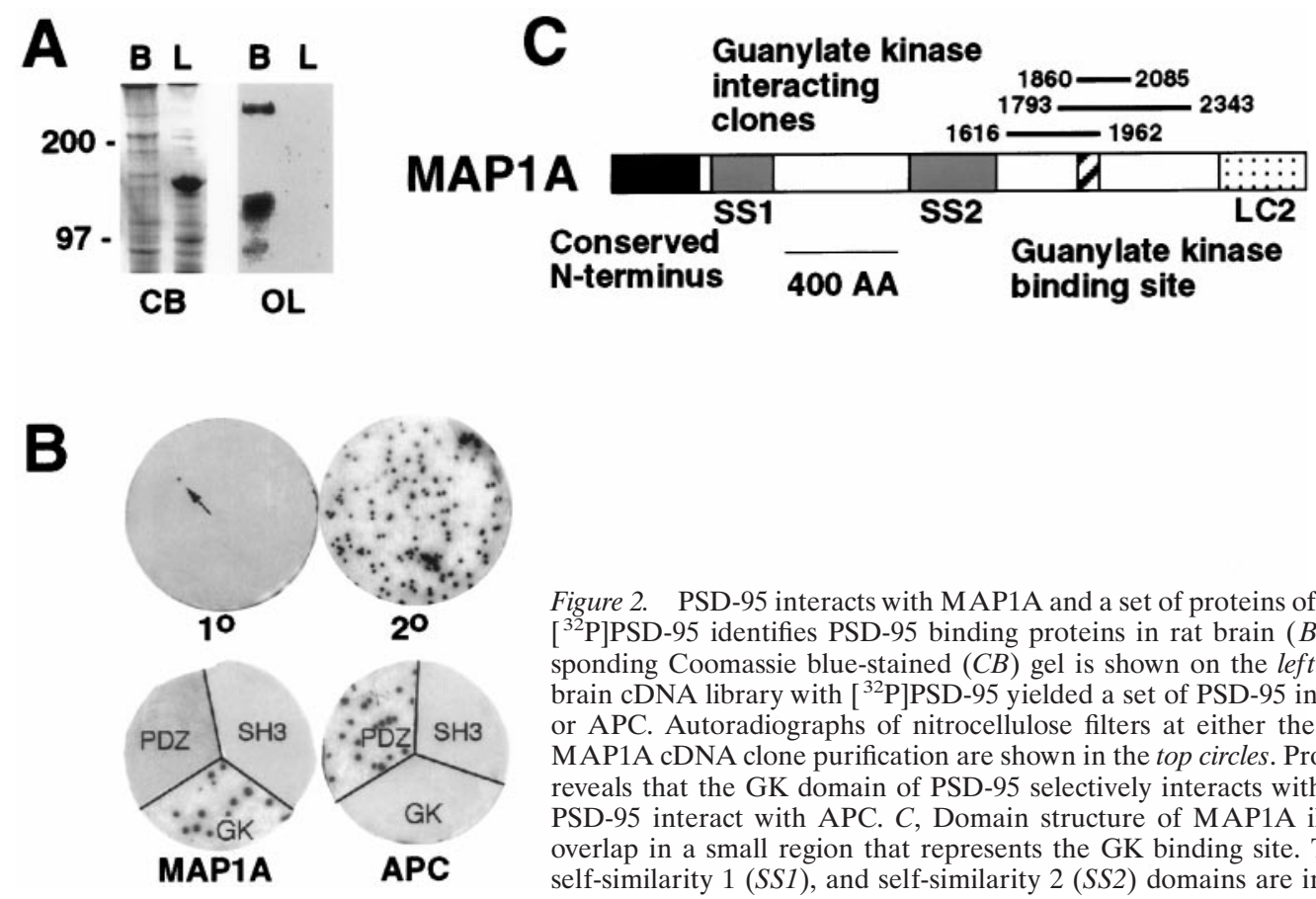

Figure 2. PSD-95 interacts with MAP1A and a set of proteins of 100-140 kDa. A, Overlay assay $(O L)$ with $\left[{ }^{32} \mathrm{P}\right] \mathrm{PSD}-95$ identifies PSD-95 binding proteins in rat brain $(B)$, but not liver $(L)$, extracts. The corresponding Coomassie blue-stained $(C B)$ gel is shown on the left. $B$, Expression cloning from a $\lambda \mathrm{gt} 11$ rat brain cDNA library with [ $\left.{ }^{32} \mathrm{P}\right] \mathrm{PSD}-95$ yielded a set of PSD-95 interacting clones encoding either MAP1A or APC. Autoradiographs of nitrocellulose filters at either the primary $\left(1^{\circ}\right)$ or secondary $\left(2^{\circ}\right)$ stage of MAP1A cDNA clone purification are shown in the top circles. Probing with ${ }^{32} \mathrm{P}$-labeled domains of PSD-95 reveals that the GK domain of PSD-95 selectively interacts with MAP1A, whereas the PDZ domains of PSD-95 interact with APC. $C$, Domain structure of MAP1A illustrates that the GK interacting clones overlap in a small region that represents the GK binding site. The locations of the light chain 2 ( $L C 2)$, self-similarity 1 (SS1), and self-similarity 2 (SS2) domains are indicated.

\begin{tabular}{llll}
\hline \multicolumn{2}{l}{ Table 1. Yeast two hybrid interactions between MAP1A and PSD-95 GK domain } & \\
Gal4 DNA binding hybrid & Gal4 activation hybrid & Colony color & Growth \\
\hline PSD-95, GK (503-724) & SV 40 (amino acids 84-708) & White & - \\
p53 (72-390) & MAP1A (1618-1962) & White & - \\
PSD-95, GK (503-724) & MAP1A (1618-1962) & Blue & + \\
PSD-95, GK (503-724) & MAP1A (1860-1962) & Blue & + \\
PSD-95, GK-Cmut (503-699) & MAP1A (1860-1962) & White & - \\
PSD-95, GK-Nmut (560-724) & MAP1A (1860-1962) & White & - \\
p53 (72-390) & SV 40 (84-708) & Blue & +
\end{tabular}

Yeast HF7c and Y187 cells were cotransformed with expression vectors encoding various GAL4-binding domain and GAL4 activation domain fusion proteins. Each transformation mixture was plated on two synthetic dextrose plates, one lacking tryptophan and leucine and the other lacking tryptophan, leucine, and histidine. Growth was measured on histidine-deficient plates, and color was measured by a $\beta$-galactosidase colorimetric filter assay (Fields and Song, 1989).

including the Purkinje neurons of cerebellum (Shiomura and Hirokawa, 1987). Dual immunofluorescent labeling of cerebellum showed a striking colocalization of PSD-93 with MAP1A in cerebellar Purkinje cells (Fig. 4B). Both proteins are concentrated in Purkinje cell bodies and in proximal dendritic processes. As a control we found that MAP2, another cytoskeletal protein enriched in Purkinje cells, was not as tightly colocalized with PSD-93. Colocalization of PSD-93 and MAP1A also was found in the dendrites, but not cell bodies, of hippocampal pyramidal neurons (Fig. 4B). To determine whether PSD-93 and MAP1A associate in vivo, we performed immunoprecipitation analyses. A polyclonal antibody to PSD-93 coimmunoprecipitated MAP1A, but it did not precipitate several other neuronal proteins, including MAP2 and calcium/calmodulin-regulated protein kinase II (Fig. 4C).

\section{GK domain binding activity is inhibited by PDZ domains}

Neuronal MAGUKs contain multiple protein-binding domains, have no known enzymatic activity, and are thought to play a scaffolding role. For a protein family with no known activity other than the binding of multiple targets simultaneously, the linear organization of the domains is strikingly conserved. The GK domain is the C-terminal domain and in all cases is separated from the $\mathrm{N}$ terminus by an SH3 domain. This conserved organization of the multiple domains of MAGUK proteins suggests that the presence and placement of the domains may play a critical role in the activity of the protein. We therefore tested whether other MAGUK protein domains influence the binding activity of the GK domain. To pursue these experiments, we found it necessary to use PSD-95 fusion proteins because we were unable to purify sufficient quantities of intact PSD-93 protein from E. coli. We found that MAP1A and the $100-140 \mathrm{kDa}$ bands from the PSD interact weakly with PSD-95 GST fusion protein when compared with the robust binding of these proteins to the isolated GK domain GST fusion (Fig. $5 A$ ). To explore this result further, we expressed a series of histidine-tagged versions of the GK domain containing either the $\mathrm{SH} 3$ domain or the $\mathrm{SH} 3$ and each of the PDZ domains. We evaluated the relative binding of these protein constructs to a purified MAP1A-GST fusion protein. We found that adding PDZ3 slightly decreased binding activity, 


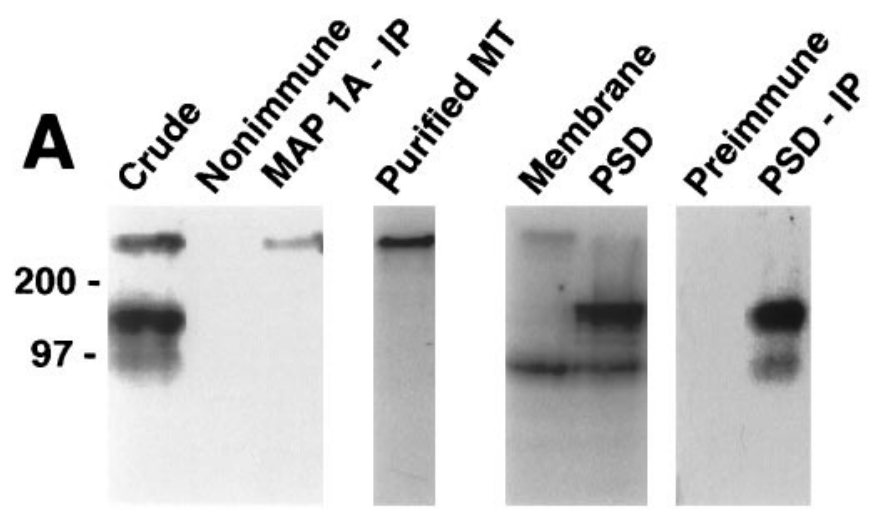

GK Overlay

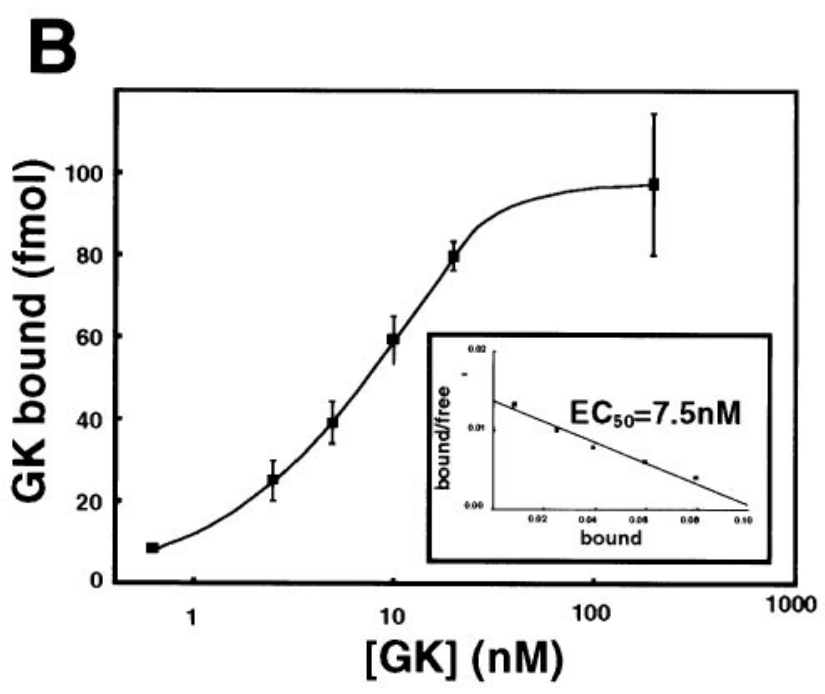

Figure 3. The GK domain potently binds to MAP1A and to proteins of the PSD. $A$, Immunoprecipitation of crude brain extracts $(100 \mu \mathrm{g})$ with a monoclonal antibody to MAP1A (Sigma), followed by overlay assay with $\left[{ }^{32} \mathrm{P}\right]$ guanylate kinase domain demonstrates that the $350 \mathrm{kDa}$ guanylate kinase-interacting protein is MAP1A. This $350 \mathrm{kDa}$ protein also is enriched specifically in a purified brain microtubule preparation $(10 \mu \mathrm{g})$. The subcellular fractionation shows the enrichment of the 100-140 kDa GK-interacting protein bands in Triton X-100 soluble synaptic membranes $(10 \mu \mathrm{g})$ and the postsynaptic density $(10 \mu \mathrm{g})$. Immunoprecipitation of SDS-solubilized PSD fraction with an antiserum to PSD-95, followed by overlay analysis, shows specific association of the 100-140 kDa bands with PSD-95. These proteins were not precipitated with preimmune serum. $B$, Saturation binding analysis shows that MAP1A binds with high affinity to the GK domain.

whereas the addition of PDZ2 and PDZ1 dramatically reduced binding to MAP1A, consistent with our results in using GST fusion proteins (Fig. 6 $A$ ).

Inhibition of the GK binding activity of MAGUKs by intramolecular PDZ domains identifies a potential mode of regulation. Autoinhibition of src family protein kinases by intramolecular $\mathrm{SH} 2$ and $\mathrm{SH} 3$ domains can be relieved by physiological ligands to the SH2 and SH3 domains (Moarefi et al., 1997; Sicheri et al., 1997; Xu et al., 1997). We therefore evaluated the possible activation of MAGUK binding activity by a C-terminal 9-mer tSXV peptide from the NMDA receptor, which is a physiological ligand for the PDZ domains (Kornau et al., 1995). Strikingly, this peptide activated the binding of MAGUK both to MAP1A and to the $100-140 \mathrm{kDa}$ bands from the PSD (see Fig. $5 B$ ). The NR2B
A
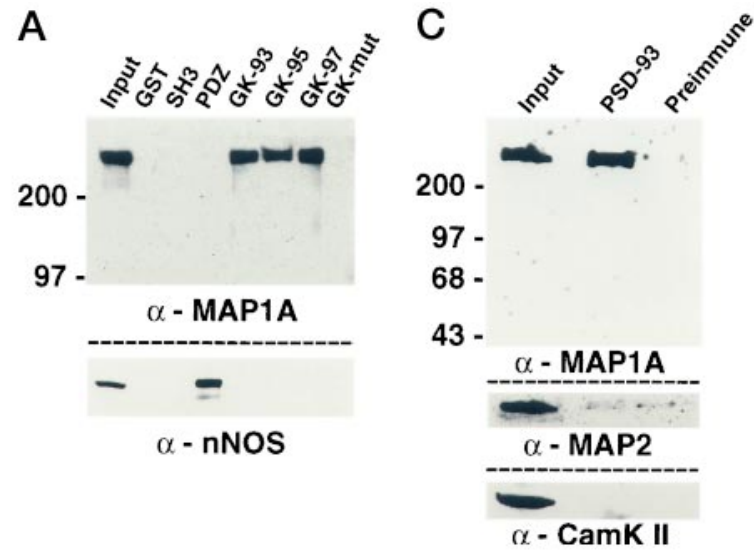

B

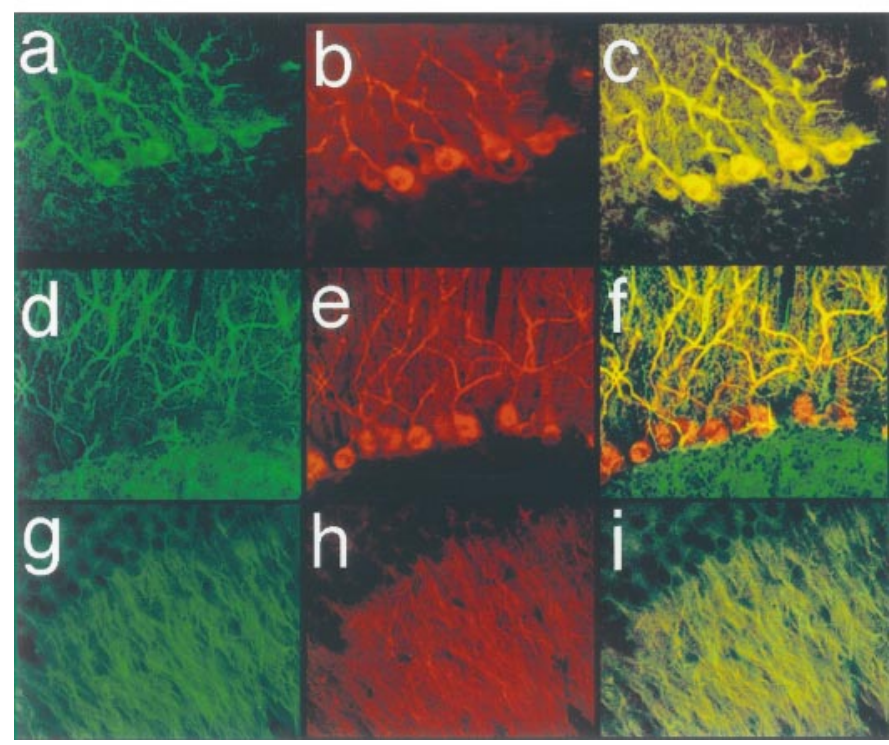

Figure 4. MAP1A associates with PSD-93 in vivo. A, MAP1A from brain extracts is retained selectively by GST fusion proteins of the GK domains of PSD-93, PSD-95, and SAP-97 but does not bind to GST fusions containing the SH3 or PDZ domains of PSD-95 or to a GK domain mutant (GK-mut) lacking the final 26 amino acids of PSD-95. nNOS specifically associates with the PDZ domains of PSD-95. "Pull-down" assays with GST fusion proteins were performed from brain extracts as described (Brenman et al., 1996a), and the resulting eluates immunoblotted sequentially for MAP1A and nNOS (Transduction Laboratories, Lexington, KY). The input is equal to $10 \%$ of the extract loaded onto the GST fusion protein columns. B, Indirect immunofluorescence (200× magnification) reveals extensive colocalization of PSD-93 and MAP1A in rat brain. MAP1A (green; $a, g$ ) and PSD-93 (red; $b, h)$ colocalize in somatodendritic profiles in Purkinje neurons in cerebellum $(a, b)$ and the CA3 region of hippocampus $(g, h)$. PSD-93 (red; $e)$ does not colocalize extensively with MAP2 ( green; $d$ ) in cerebellum. Composite images show the colocalization of signals (yellow; $c, f, i$ ). $C$, Antiserum to PSD-93 specifically immunoprecipitates MAP1A from brain extracts. Immunoprecipitation followed by immunoblotting reveals that MAP1A is associated with PSD-93 in Triton X-100-solubilized rat cerebellar extracts. Conversely, MAP2 and calcium/calmodulin-dependent protein kinase II (CamK II) do not coimmunoprecipitate with PSD-93.

peptide effect was dose-dependent and saturable. Half-maximal effect occurred at a peptide concentration of $\sim 30 \mu \mathrm{M}$ (Fig. $5 B$ ). Control NR2B peptides with point mutations at the critical tSXV (Kornau et al., 1995) residues had a negligible influence on binding at all concentrations that were tested (Fig. 5B). Further- 

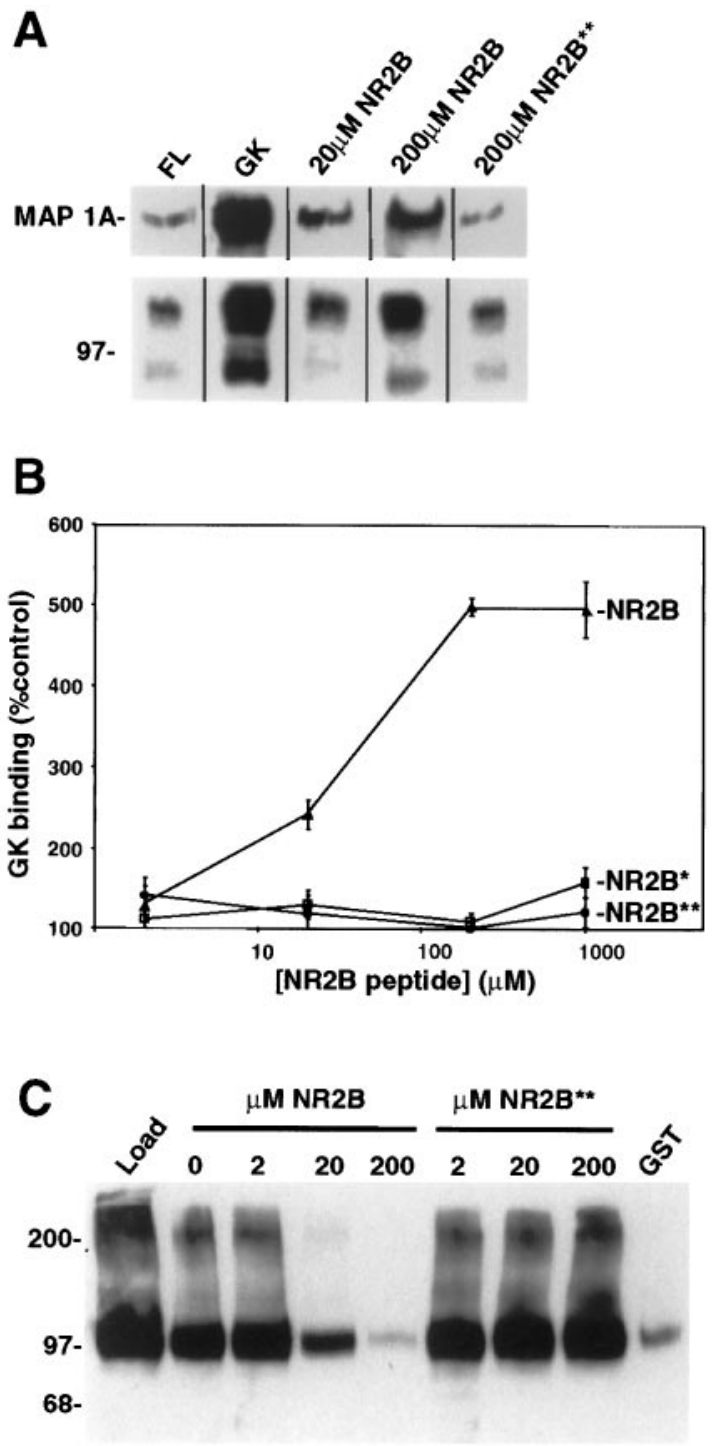

$\alpha \mathbf{K v 1 . 4}$

Figure 5. GK binding activity of full-length MAGUK is stimulated by a PDZ ligand. $A$, Overlay assay was used to compare the binding activity of full-length PSD-95 with that of the isolated GK domain of PSD-95. Autoradiography shows that the isolated GK domain interacts strongly with MAP1A and the 100-140 kDa bands from brain extracts, whereas the full-length MAGUK shows much weaker binding activity $(\sim 5 \%)$. A 9-amino-acid peptide corresponding to the tail of NR2B, KLSSIESDV $(N R 2 B)$, dramatically increases the binding activity of full-length MAGUK (approximately eightfold), whereas a similar mutated peptide, KLSSIEADA $\left(N R 2 B^{* *}\right)$, is ineffective. After autoradiography the interacting protein bands were excised and counted in liquid scintillant. $B$, NR2B peptide stimulates GK binding activity of full-length MAGUK to purified MAP1A fusion protein. NR2B peptides with either a single mutation KLSSIESDA (NR2B*) or a double mutation $\left(N R 2 B^{* *}\right)$ do not activate GK binding activity. GK binding activity was quantitated by dot blot assay, monitoring the binding of full-length PSD-95 to a purified MAP1A fusion protein, as described in Materials and Methods. $C$, The affinity of NR2B peptide for PDZ domains in solution is in the micromolar range. PSD-95-GST fusion proteins were used to "pull down" $\mathrm{K}^{+}$ channel $\mathrm{K}_{\mathrm{v}} 1.4$ from Triton X-100-solubilized brain extract. NR2B peptides were added to the pulldown to block the association of the fusion proteins with $\mathrm{K}_{\mathrm{v}} 1.4$ in vitro. Mutant peptide had no effect.
A
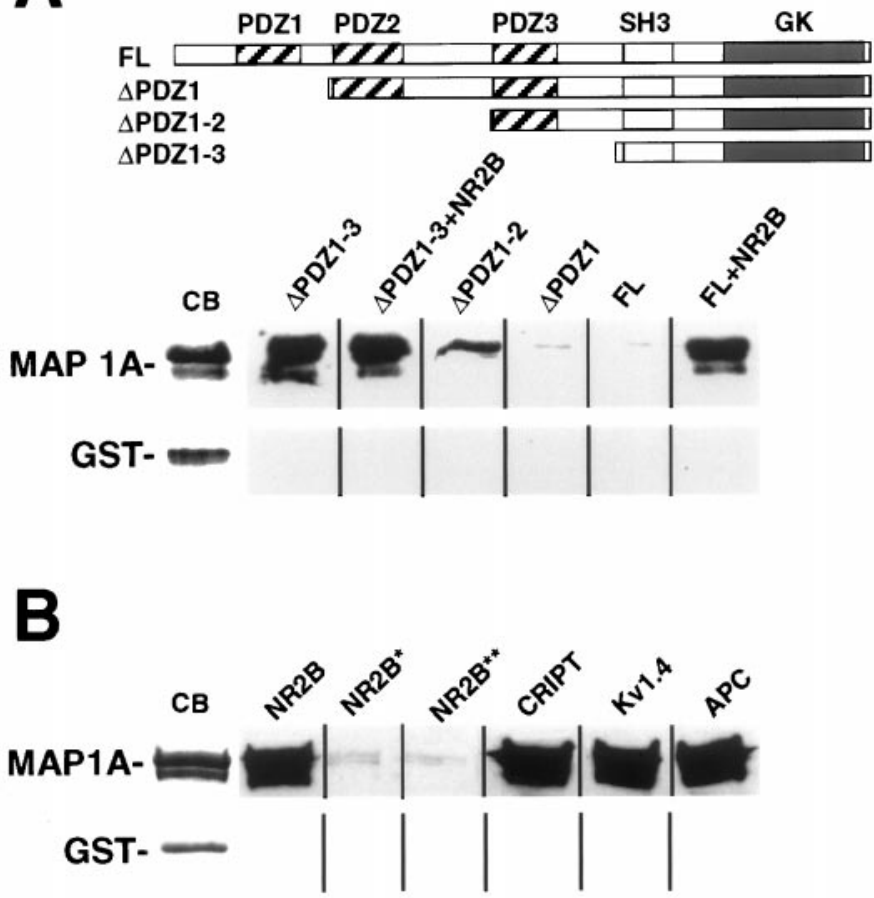

C
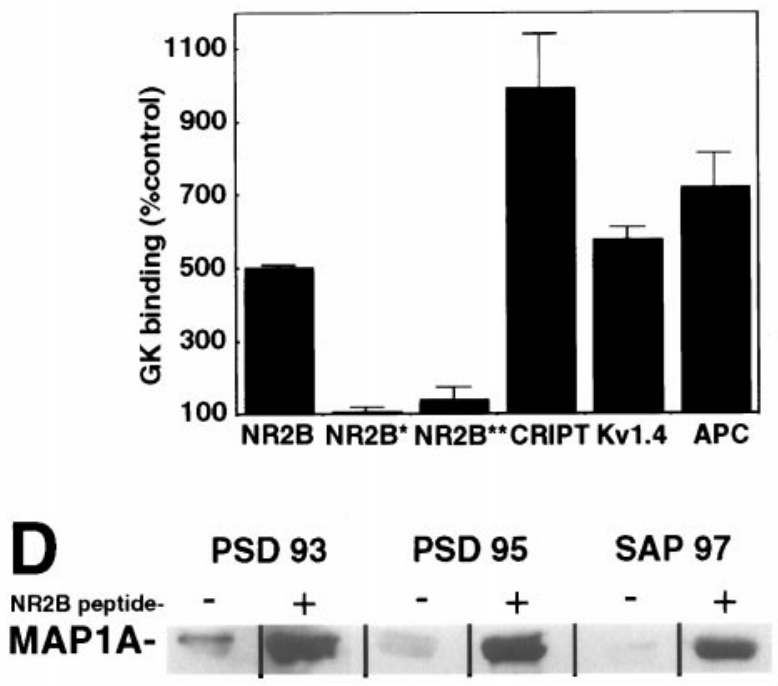

Figure 6. PDZ domains 2 and 3 autoinhibit GK domain. $A$, Schematic showing design of histidine-tagged fusion proteins of PSD-95. "Far Western" analysis demonstrates that PDZ2 and PDZ3 domains inhibit the binding of the GK domain to a purified MAP1A-GST fusion protein. A peptide corresponding to the tail of NR2B, but not a mutated peptide NR2B*, stimulates the binding activity of the full-length MAGUK to purified MAP1A. The NR2B peptide did not affect the binding of the GK construct lacking PDZ domains $(\triangle P D Z 1-3)$. None of the MAGUK protein constructs bound to GST alone. $C B$, Coomassie blue. $B$, C-terminal peptides (9-mers; at $200 \mu \mathrm{M})$ corresponding to NR2B, $\mathrm{K}^{+}$channel $\mathrm{K}_{\mathrm{v}} 1.4$, APC, or CRIPT all stimulate the binding of full-length MAGUK to MAP1A, as measured by far Western assay. $C$, Quantitative binding assay shows that distinct PDZ domain ligands $(200 \mu \mathrm{M})$ stimulate the GK binding activity of full-length MAGUK from 5- to 10-fold. The greatest activation is observed consistently with CRIPT, a PDZ3 ligand. GK binding activity was quantitated by dot blot assay, monitoring the binding of full-length PSD-95 to a purified MAP1A fusion protein. D, A C-terminal peptide corresponding to NR2B stimulates the binding of three distinct MAGUKs, PSD-93, PSD-95, and SAP-97, to MAP1A. 
more, the NR2B peptide did not influence the binding activity of the isolated GK domain.

Because we determined that the NR2B peptide has an $\mathrm{EC}_{50}$ of $30 \mu \mathrm{M}$ for stimulating GK binding activity, we compared this with the binding affinity of the NR2B 9-mer peptide to full-length PSD-95 in solution (Fig. 5C). To determine the binding affinity, we used a PSD-95 GST fusion construct to "pull down" ion channel $\mathrm{K}_{\mathrm{v}} 1.4$ from brain homogenates. $\mathrm{K}_{\mathrm{v}} 1.4$ contains $\mathrm{a}$ C-terminal tSXV motif that potently binds PDZ1/2 of PSD-95. We found the interaction of PSD-95 and $K_{v} 1.4$ was specifically blocked by the NR2B peptide, with half-maximal effects at $\sim 20$ $\mu \mathrm{M}$ (Fig. $5 C$ ). Thus the NR2B peptide shows comparable affinity both for interacting with PSD-95 PDZ domains and for stimulating GK binding activity.

A variety of proteins associates with PDZ domains of MAGUKs via C-terminal polypeptide interactions (Kornau et al., 1997). These include NMDA receptors (Kornau et al., 1995), which occur at the PSD; Shaker $\mathrm{K}^{+}$channels, which are primarily presynaptic (Kim et al., 1995); and APC (Matsumine et al., 1996) and CRIPT (Niethammer et al., 1998), which associate with microtubules (Smith et al., 1994). We found that C-terminal peptides corresponding to each of these PDZ binding proteins stimulated the GK binding activity of intact PSD-95 (Fig. 6B). The peptide that was most effective at activating GK binding to MAP1A had the highest affinity for PDZ3 and corresponded to the CRIPT protein C-terminal tail (Niethammer et al., 1998) (Fig. 6C). CRIPT is a microtubule-associated protein and coimmunoprecipitates with PSD-95 and tubulin from brain homogenates. Our experiments suggest that CRIPT may play a dual role in linking MAGUK proteins to the tubulin-based cytoskeleton in MAP1A-containing neurons. We next asked whether the activation of GK binding by PDZ ligands was a common feature of neuronal MAGUK proteins. Indeed, the GK binding activity of all three MAGUKs that were tested, PSD-93, PSD-95, and SAP97 , were stimulated by a peptide corresponding to the tail of NR2B (Fig. 6D).

\section{DISCUSSION}

This work establishes dendritic microtubules as a novel cytoskeletal link for MAGUK proteins in some neuronal populations. The isolated GK domain of MAGUKs binds to MAP1A with nanomolar affinity and also binds to proteins of $100-140 \mathrm{kDa}$ in the PSD. PSD-93 occurs along dendritic microtubules in cerebellar Purkinje cells, and a PSD-93/MAP1A complex occurs in vivo. Mutations in the GK domain of $d l g$ that cause cytoskeletal defects in Drosophila disrupt interaction with MAP1A, which is consistent with a physiological role for this interaction. Additional evidence presented here suggests that this high-affinity binding site is regulated by PDZ domains. This work presents a novel mechanism for MAGUKs to mediate interactions between the cytoskeleton and the plasma membrane in neurons and other cells.

\section{PSD-93 occurs along dendritic microtubules and at the PSD}

Previous studies have focused on the synaptic distributions of neuronal MAGUKs. This work has shown that SAP-102 occurs postsynaptically (Muller et al., 1996), SAP-97 occurs presynaptically (Muller et al., 1995), and PSD-95 occurs at both presynaptic (Kistner et al., 1993) and postsynaptic sites (Hunt et al., 1996). Ultrastructural studies of these MAGUKs at nonsynaptic sites in brain previously have not been described in detail. Our biochem- ical studies indicate that PSD-95, PSD-93, and SAP-97 are all capable of interacting with MAP1A. In Purkinje neurons we find PSD-93 both at PSDs and in prominent association with dendritic microtubules. This dual localization is reminiscent of another receptor-associated protein, gephyrin, which is a tubulin-binding protein and clusters inhibitory glycine receptors at postsynaptic sites (Kuhse et al., 1995). PSD-93 is localized to excitatory synapses in cerebellar Purkinje neurons and may interact with NMDA receptors that are expressed during cerebellar development (Rosenmund et al., 1992). Because functional NMDA receptors are not thought to be expressed abundantly in adult Purkinje cells (Yuzaki et al., 1996), the role of PSD-93 in postsynaptic densities of the adult cerebellum is unclear. It is possible that MAGUK proteins play an important structural and scaffolding role at postsynaptic densities independent of their receptor clustering activity. Other MAGUK ligands are expressed in Purkinje cells, in particular CRIPT and GKAPs, both of which occur at the PSD (Naisbitt et al., 1997; Niethammer et al., 1998). Via interactions with these proteins, PSD-93 might anchor signal transduction molecules to the PSD of Purkinje cells. PSD-93 in the only known MAGUK expressed in Purkinje neurons and its localization to the PSD in the absence of active NMDA receptors suggest that MAGUKs have roles at excitatory synapses in addition to clustering NMDA receptors.

Although there is conflicting evidence as to the presence and role of a tubulin-based cytoskeleton at the PSD (Walters and Matus, 1975; Harris and Kater, 1994), tubulin copurifies with the PSD fraction, and MAP2 and CRIPT localize to the PSD (Niethammer et al., 1998). Together with the striking redistribution of PSD-95 to microtubules when cotransfected with CRIPT in heterologous cells, these data indicate that CRIPT directly or indirectly may anchor MAGUKs to some form of a tubulin-based cytoskeleton at the PSD (Niethammer et al., 1998). The localization of PSD-93 to dendritic microtubules and its association with microtubule-binding proteins MAP1A, APC, and CRIPT suggest that interactions with the microtubule-based cytoskeleton may play a general role in MAGUK protein localization and function.

\section{The GK domain binds to MAP1A and to PSD proteins}

This study provides further insight into molecular functions for the GK domain of neuronal MAGUKs. Although the primary amino acid sequence resembles yeast GK (Woods and Bryant, 1991), enzymatic activity has not yet been reported for a MAGUK, and amino acid residues critical for GK enzyme activity generally are not conserved in MAGUKs. Instead, the GK domain of MAGUKs is identified as a critical region for protein interactions, specifically with proteins of the neuronal cytoskeleton. Overlay analysis of crude brain homogenates with the GK domain identified only MAP1A and a set of 100-140 kDa bands that occur in the PSD. These $100-140 \mathrm{kDa}$ proteins likely are related to the GK-associated proteins (GKAP or SAPAPs) that bind to neuronal MAGUKs and were identified with the yeast two-hybrid system (Kim et al., 1997; Takeuchi et al., 1997). Similar to the protein bands detected here, GKAP/SAPAPs are brain-specific and enriched at the PSD. Functions for GKAP/ SAPAPs at the PSD are uncertain, because these proteins have a novel sequence.

What are the functional implications for the interaction of MAGUKs with both MAP1A and with proteins at the PSD? MAPs regulate microtubule dynamics and play a central role in neuronal morphogenesis (Kaech et al., 1996). Mutant mice heterozygous for a MAP1B deletion have diminished levels of 
MAP1A in cerebellar Purkinje neurons and have abnormal Purkinje cell dendritic structure (Edelmann et al., 1996). MAGUKs, on the other hand, regulate both cytoskeletal structure and also mediate receptor clustering at the PSD. Mutant alleles of $d l g$ demonstrate that these two functions are mediated by distinct MAGUK domains. The three PDZ domains are required for proper postsynaptic localization of $d l g$ and for clustering of Shaker $\mathrm{K}^{+}$channels at the PSD (Tejedor et al., 1997). A $d l g$ mutant (v59) missing most of the GK domain clusters receptors normally at the postsynaptic density (Tejedor et al., 1997) but displays abnormal postsynaptic structure (Lahey et al., 1994). Further understanding of MAGUK functions in mammals awaits the characterization of targeted mouse mutants.

\section{Intramolecular PDZ domain interactions regulate GK binding activity}

Previous studies have characterized PDZ motifs as modular protein-protein interaction domains (Sheng, 1996; Kornau et al., 1997; Craven and Bredt, 1998). PDZ domains often bind to specific C-terminal consensus sequences (Songyang et al., 1997; Stricker et al., 1997), but PDZ-PDZ complexes also have been described (Brenman et al., 1996a). Differential binding specificity is dictated by the distinct structure of each PDZ domain. Single PDZ domains are found in nNOS and disheveled protein and are required for targeting these proteins to sites of cell-cell contact (Yanagawa et al., 1995; Brenman et al., 1996a). Multiple PDZ domains occur in MAGUKs, INAD (inactivation no-after potential) (Shieh and Zhu, 1996), and GRIP (glutamate receptorinteracting protein) (Dong et al., 1997) proteins that appear to function as molecular scaffolds and signal transduction organizers.

Our work demonstrates that PDZ domains also may mediate intramolecular interactions to regulate protein function. Autoinhibition of the GK domain by PDZ motifs is reminiscent of the regulation of Tec and src family tyrosine kinases by intramolecular SH2 and SH3 domain interactions (Andreotti et al., 1997; Sicheri et al., 1997; Xu et al., 1997). Src family kinases can be activated by $\mathrm{SH} 3$ domain displacement mediated by appropriate polypeptide ligands to the SH3 domain (Moarefi et al., 1997). Similarly, GK domain binding activity of MAGUK is activated by PDZ domain ligands. By analogy to src family kinases, we suspect that ligands of the SH3 domain of MAGUKs also may activate GK domain binding activity. We are presently unable to test this hypothesis because protein ligands for the $\mathrm{SH} 3$ domain remain unknown.

In our experiments, micromolar concentrations of PDZ binding peptides are required to potentiate the GK binding activity of the full-length MAGUK. Some previous studies have reported nanomolar affinities for the interaction NR2B with PDZ domains (Muller et al., 1996), whereas other reported affinities (Niethammer et al., 1998), including those presented here, are in the micromolar range. The discrepancy between these results is not clearly resolved. However, the affinities of peptide ligands for PDZs in our system, as determined by competitive binding to $\mathrm{K}_{\mathrm{v}} 1.4$, are consistently in the micromolar range $(20-30 \mu \mathrm{M})$, similar to the concentration required for half-maximal stimulation of GK binding activity. Together with the sequence specificity for the peptides, our evidence strongly suggests that the effect described here is attributable to the binding of the peptide to PDZ domains and the perturbation of an intramolecular inhibitory interaction. Structural studies of full-length MAGUKs may be needed to determine the molecular mechanism for this effect.

What might be the role for autoinhibitory PDZ domains in
MAGUK function? One possibility is that this mechanism helps to ensure the proper targeting of MAGUKs to specific subcellular sites. In this model, high-affinity MAGUK binding to MAP1A occurs only when the PDZ domains first interact with an appropriate ligand, such as APC, or other unknown PDZ ligands in the dendritic cytoplasm. A similar situation would occur with NMDA receptors or CRIPT at the PSD. Synaptic MAGUK binding to GKAPs and other GK ligands might be activated or stabilized when the PDZ domains are bound and the intramolecular inhibition is disengaged. This model for "mechanism-based protein targeting" could help to account for the precise segregation of signal transduction cascades at the synapse.

A second possibility is that the accessibility and phosphorylation (Cohen et al., 1996) of PDZ ligands are dynamic in neurons, and this in turn would regulate GK binding activity. For example, the cytoplasmic tails of certain NMDA receptor subunits are complexed with $\alpha 2$-actinin, and the tails are released after receptor stimulation in a calcium/calmodulin-dependent manner (Rosenmund and Westbrook, 1993; Ehlers et al., 1996; Wyszynski et al., 1997). Activation of the cytoskeletal-binding function of MAGUKs by the free tail of the NMDA receptor then would provide a mechanism for dynamic regulation of postsynaptic structure. PDZ motifs occur in diverse classes of mammalian proteins and appear to be particularly important in organizing signal transduction cascades in neurons. PDZ domains now have been found in bacteria, yeast, and plants also (Ponting, 1997). Regulation of protein function by intramolecular interactions may be a common function for PDZ domains.

\section{REFERENCES}

Andreotti AH, Bunnell SC, Feng S, Berg LJ, Schreiber SL (1997) Regulatory intramolecular association in a tyrosine kinase of the Tec family. Nature 385:93-97.

Blanar MA, Rutter WJ (1992) Interaction cloning: identification of a helix-loop-helix zipper protein that interacts with c-Fos. Science 256:1014-1018.

Brenman JE, Chao DS, Gee SH, McGee AW, Craven SE, Santillano DR, Huang F, Xia H, Peters MF, Froehner SC, Bredt DS (1996a) Interaction of nitric oxide synthase with the postsynaptic density protein PSD-95 and $\alpha-1$ syntrophin mediated by PDZ motifs. Cell 84:757-767.

Brenman JE, Christopherson KS, Craven SE, McGee AW, Bredt DS (1996b) Cloning and characterization of postsynaptic density 93 (PSD93), a nitric oxide synthase-interacting protein. J Neurosci 16:7407-7415.

Budnik V, Koh YH, Guan B, Hartmann B, Hough C, Woods D, Gorczyca M (1996) Regulation of synapse structure and function by the Drosophila tumor suppressor gene dlg. Neuron 17:627-640.

Chen H-J, Rojas-Soto M, Oguni A, Kennedy MB (1998) A synaptic Ras-GTPase activating protein (p135 SynGAP) inhibited by CaM kinase II. Neuron 20:895-904.

Cho KO, Hunt CA, Kennedy MB (1992) The rat brain postsynaptic density fraction contains a homolog of the Drosophila discs-large tumor suppressor protein. Neuron 9:929-942.

Cohen NA, Brenman JE, Snyder SH, Bredt DS (1996) Binding of the inward rectifier $\mathrm{K}^{+}$channel Kir 2.3 to PSD-95 is regulated by protein kinase A phosphorylation. Neuron 17:759-767.

Cravchik A, Reddy D, Matus A (1994) Identification of a novel microtubule-binding domain in microtubule-associated protein $1 \mathrm{~A}$ (MAP1A). J Cell Sci 107:661-672.

Craven SE, Bredt DS (1998) PDZ proteins organize synaptic signaling pathways. Cell 93:495-498.

Dong H, O'Brien RJ, Fung ET, Lanahan AA, Worley PF, Huganir RL (1997) GRIP: a synaptic PDZ domain-containing protein that interacts with AMPA receptors [see comments]. Nature 386:279-284.

Edelmann W, Zervas M, Costello P, Roback L, Fischer I, Hammarback JA, Cowan N, Davies P, Wainer B, Kucherlapati R (1996) Neuronal abnormalities in microtubule-associated protein $1 \mathrm{~B}$ mutant mice. Proc Natl Acad Sci USA 93:1270-1275.

Ehlers MD, Zhang S, Bernhadt JP, Huganir RL (1996) Inactivation of 
NMDA receptors by direct interaction of calmodulin with the NR1 subunit. Cell 84:745-755.

Fields S, Song O (1989) A novel genetic system to detect protein-protein interactions. Nature 340:245-246.

Guan B, Hartmann B, Kho YH, Gorczyca M, Budnik V (1996) The Drosophila tumor suppressor gene, $d l g$, is involved in structural plasticity at a glutamatergic synapse. Curr Biol 6:695-706.

Harris KM, Kater SB (1994) Dendritic spines: cellular specializations imparting both stability and flexibility to synaptic function. Annu Rev Neurosci 17:341-371.

Hoskins R, Hajnal AF, Harp SA, Kim SK (1996) The C. elegans vulval induction gene lin-2 encodes a member of the MAGUK family of cell junction proteins. Development 122:97-111.

Hunt AC, Schenker LJ, Kennedy MB (1996) PSD-95 is associated with the postsynaptic density and not with the presynaptic membrane at forebrain synapses. J Neurosci 16:1380-1388.

Kaech S, Ludin B, Matus A (1996) Cytoskeletal plasticity in cells expressing neuronal microtubule-associated proteins. Neuron 17:1189-1199.

Kennedy MB (1997) The postsynaptic density at glutamatergic synapses. Trends Neurosci 20:264-268.

Kim E, Niethammer M, Rothschild A, Jan YN, Sheng M (1995) Clustering of Shaker-type $\mathrm{K}^{+}$channels by direct interaction with the PSD-95/SAP90 family of membrane-associated guanylate kinases. Nature 378:85-88.

Kim E, Cho K-O, Rothschild A, Sheng M (1996) Heteromultimerization and NMDA receptor clustering activity of Chapsyn-110, a novel member of the PSD-95 family of synaptic proteins. Neuron 17:103-113.

Kim E, Naisbitt S, Hsueh YP, Rao A, Rothschild A, Craig AM, Sheng M (1997) GKAP, a novel synaptic protein that interacts with the guanylate kinase-like domain of the PSD-95/SAP90 family of channel clustering molecules. J Cell Biol 136:669-678.

Kim JH, Liao D, Lau L-F, Huganir RL (1998) SynGAP: a synaptic RasGAP that associates with the PSD-95/SAP90 protein family. Neuron 20:683-691.

Kim SK (1995) Tight junctions, membrane-associated guanylate kinases, and cell signaling. Curr Opin Cell Biol 7:641-649.

Kistner U, Wenzel BM, Veh RW, Cases-Langhoff C, Garner AM, Appeltauer U, Voss B, Gundelfinger ED, Garner CC (1993) SAP90, a rat presynaptic protein related to the product of the Drosophila tumor suppressor gene $d l g-A$. J Biol Chem 268:4580-4583.

Kornau H-C, Schenker LT, Kennedy MB, Seeburg PH (1995) Domain interaction between NMDA receptor subunits and the postsynaptic density protein PSD-95. Science 269:1737-1740.

Kornau H-C, Seeburg PH, Kennedy MB (1997) Interaction of ion channels and receptors with PDZ domains. Curr Opin Neurobiol 7:368-373.

Kuhse J, Betz H, Kirsch J (1995) The inhibitory glycine receptor: architecture, synaptic localization, and molecular pathology of a postsynaptic ion-channel complex. Curr Opin Neurobiol 5:318-323.

Lahey T, Gorczyca M, Jia XX, Budnik V (1994) The Drosophila tumor suppressor gene $d l g$ is required for normal synaptic bouton structure. Neuron 13:823-835.

Langkopf A, Hammarback JA, Muller R, Vallee RB, Garner CC (1992) Microtubule-associated proteins $1 \mathrm{~A}$ and LC2. Two proteins encoded in one messenger RNA. J Biol Chem 267:16561-16566.

Lau LF, Mammen A, Ehlers MD, Kindler S, Chung WJ, Garner CC, Huganir RL (1996) Interaction of the $N$-methyl-D-aspartate receptor complex with a novel synapse-associated protein, SAP102. J Biol Chem 21622-21628.

Matsumine A, Ogai A, Senda T, Okumura N, Satoh K, Baeg GH, Kawahara T, Kobayashi S, Okada M, Toyoshima K, Akiyama T (1996) Binding of APC to the human homolog of the Drosophila discs-large tumor suppressor protein [see comments]. Science 272:1020-1023.

Matus A (1988) Microtubule-associated proteins: their potential role in determining neuronal morphology. Annu Rev Neurosci 11:29-44.

Moarefi I, LaFevre-Bernt M, Sicheri F, Huse M, Lee CH, Kuriyan J, Miller WT (1997) Activation of the Src-family tyrosine kinase Hck by SH3 domain displacement [see comments]. Nature 385:650-653.

Muller BM, Kistner U, Veh RW, Cases-Langhoff C, Becker B, Gundelfinger ED, Garner CC (1995) Molecular characterization and spatial distribution of SAP97, a novel presynaptic protein homologous to SAP90 and the Drosophila discs-large tumor suppressor protein. J Neurosci 15:2354-2366.

Muller BM, Kistner U, Kindler S, Chung WK, Kuhlendahl S, Fenster SD, Lau L-F, Veh RW, Huganir RL, Gundelfinger ED, Garner CC (1996)
SAP102, a novel postsynaptic protein that interacts with NMDA receptor complexes in vivo. Neuron 17:255-265.

Naisbitt S, Kim E, Weinberg RJ, Rao A, Yang FC, Craig AM, Sheng M (1997) Characterization of guanylate kinase-associated protein, a postsynaptic density protein at excitatory synapses that interacts directly with postsynaptic density-95/synapse-associated protein 90 . J Neurosci 17:5687-5696.

Niethammer M, Valtschanoff JG, Kapoor TM, Allison DW, Weinberg RJ, Craig AM, Sheng M (1998) CRIPT, a novel postsynaptic protein that binds to the third PDZ domain of PSD-95/SAP90. Neuron 20:693-707.

Pedrotti B, Colombo R, Islam K (1994) Microtubule-associated protein MAP1A is an actin-binding and crosslinking protein. Cell Motil Cytoskeleton 29:110-116.

Ponting CP (1997) Evidence for PDZ domains in bacteria, yeast, and plants. Protein Sci 6:464-468.

Rosenmund C, Westbrook GL (1993) Calcium-induced actin depolymerization reduces NMDA channel activity. Neuron 10:805-814.

Rosenmund C, Legendre P, Westbrook GL (1992) Expression of NMDA channels on cerebellar Purkinje cells acutely dissociated from newborn rats. J Neurophysiol 68:1901-1905.

Sheng M (1996) PDZs and receptor/channel clustering: rounding up the latest suspects [comment]. Neuron 17:575-578.

Shieh BH, Zhu MY (1996) Regulation of the TRP $\mathrm{Ca}^{2+}$ channel by INAD in Drosophila photoreceptors. Neuron 16:991-998.

Shiomura Y, Hirokawa N (1987) The molecular structure of microtubule-associated protein 1A (MAP1A) in vivo and in vitro. An immunoelectron microscopy and quick-freeze, deep-etch study. J Neurosci 7:1461-1469.

Sicheri F, Moarefi I, Kuriyan J (1997) Crystal structure of the Src family tyrosine kinase Hck [see comments]. Nature 385:602-609.

Smith KJ, Levy DB, Maupin P, Pollard TD, Vogelstein B, Kinzler KW (1994) Wild-type but not mutant APC associates with the microtubule cytoskeleton. Cancer Res 54:3672-3675.

Songyang Z, Fanning AS, Fu C, Xu J, Marfatia SM, Chishti AH, Crompton A, Chan AC, Anderson JM, Cantley LC (1997) Recognition of unique carboxyl-terminal motifs by distinct PDZ domains. Science 275:73-77.

Stricker NL, Christopherson KS, Yi BA, Schatz PJ, Raab RW, Dawes G, Bassett Jr DE, Bredt DS, Li M (1997) PDZ domain of neuronal nitric oxide synthase recognizes novel $\mathrm{C}$-terminal peptide sequences as determined by in vitro selection. Nat Biotechnol 15:336-342.

Takeuchi M, Hatam Y, Kirao K, Toyoda A, Irie M, Takai Y (1997) SAPAPs. J Biol Chem 272:11943-11951.

Tejedor FJ, Bokhari A, Rogero O, Gorczyca M, Zhang J, Kim E, Sheng M, Budnik V (1997) Essential role for $d l g$ in synaptic clustering of Shaker $\mathrm{K}^{+}$channels in vivo. J Neurosci 17:152-159.

Thomas U, Kim E, Kuhlendahl S, Koh YH, Gundelfinger ED, Sheng M, Garner CC, Budnik V (1997) Synaptic clustering of the cell adhesion molecule fasciclin II by discs-large and its role in the regulation of presynaptic structure. Neuron 19:787-799.

Vallee RB (1986) Purification of brain microtubules and microtubuleassociated protein 1 using taxol. Methods Enzymol 134:104-115.

Vinson CR, LaMarco KL, Johnson PF, Landschulz WH, McKnight SL (1988) In situ detection of sequence-specific DNA binding activity specified by a recombinant bacteriophage. Genes Dev 2:801-806.

Walters BB, Matus AI (1975) Tubulin in postsynaptic junctional lattice. Nature 257:496-498.

Woods DF, Bryant PJ (1991) The discs-large tumor suppressor gene of Drosophila encodes a guanylate kinase homolog localized at septate junctions. Cell 66:451-464.

Wyszynski M, Lin J, Rao A, Nigh E, Beggs AH, Craig AM, Sheng M (1997) Competitive binding of $\alpha$-actinin and calmodulin to the NMDA receptor. Nature 385:439-442.

Xu W, Harrison SC, Eck MJ (1997) Three-dimensional structure of the tyrosine kinase c-Src [see comments]. Nature 385:595-602.

Yanagawa S, van Leeuwen F, Wodarz A, Klingensmith J, Nusse R (1995) The disheveled protein is modified by wingless signaling in Drosophila. Genes Dev 9:1087-1097.

Yuzaki M, Forrest D, Verselis LM, Sun SC, Curran T, Connor JA (1996) Functional NMDA receptors are transiently active and support the survival of Purkinje cells in culture. J Neurosci 16:4651-4661.

Zito K, Fetter RD, Goodman CS, Isacoff EY (1997) Synaptic clustering of Fasciclin II and Shaker: essential targeting sequences and role of $d l g$. Neuron 19:1007-1016. 